\title{
Pelatihan Penyegaran Keterampilan Dasar Mengajar Bagi Guru Sekolah Dasar di Kota Kupang
}

\author{
Taty R. Koroh ${ }^{1)}$, Paulina Riwu Ga ${ }^{2}$, Andriyani Afliyanti Dua Lehan ${ }^{3)}$, Netty E.A. Nawa ${ }^{4)}$ \\ Pendidikan Guru Sekolah Dasar, Fakultas Keguruan dan Ilmu Pendidikan, Universitas Nusa \\ Cendana, Indonesia ${ }^{1,2), 3), 4)}$ \\ email: tatikoroh@staf.undana.ac.id ${ }^{11}$
}

\begin{tabular}{|l|l|l|}
\hline Dikirim: 02-02-2021 & Direvisi: 09-04-2021 & Diterbitkan: 31-08-2021
\end{tabular}

\begin{abstract}
Abstrak
Pengabdian Masyarakat ini bertujuan untuk menyelengarakan kegiatan Pelatihan Penyegaran Keterampilan Dasar Mengajar bagi guru-guru SD di Kota Kupang, selain itu juga peserta pelatihan mampu menguasai konsep keterampilan dasar mengajar guru sebagai prasyarat terlaksananya program merdeka belajar di kelas, dan peserta mampu merubah pandangan dan sikap guru yang berkarkter feodalis ke karakter guru humanisme. Adapun metede yang digunakan dalam pengabdian masyarakat ini yaitu menggunakan metode ceramah, tanya jawab dan praktik/simulasi langsung. hasil/temuan yang diperoleh guru belum menguasai keterampilan dasar mengajar oleh karena itu produk yang dihasilkan dari kegiatan pengabdian masyarakat ini guru-guru dapat menguasai kembali keterampilan dasar mengajar.
\end{abstract}

\section{Kata Kunci : Keterampilan dasar, Mengajar}

\begin{abstract}
This Community Service aims to hold a Basic Teaching Skills Refresher activity for elementary school teachers in Kupang City, besides that the training participants are able to master the concept of basic teaching skills as a prerequisite for implementing the independent learning program in class, and participants are able to change the views and attitudes of teachers. the feudal character to the character of the teacher of humanism. The methods used in this community service are lectures, questions and answers and direct practice / simulation. the results / findings obtained by the teacher have not mastered basic teaching skills, therefore the products produced from this community service activity teachers can regain basic teaching skills.
\end{abstract}

\section{Keywords : Basic Skill, Teaching}

\section{PENDAHULUAN}

Kementerian Pendidikan dan Kebudayaan Republik Indonesia mendesain program unggulan antara lain yakni merdeka belajar. Merdeka belajar tentu saja memiliki arti dan makna yang luas. Merdeka belajar dikonsepkan sebagai bentuk pemberian kebebasan kepada siswa dan atau mahasiswa untuk memilih sumber-sumber belajar yang sesuai dengan minat dan bakatnya sehingga dapat terjadi proses belajar yang bermakna. Subjek belajar itu sendiri adalah siswa, dan supaya siswa belajar dibutuhkan stimulus-stimulus dan pemberian berbagai bentuk motivasi oleh guru baik sebelum, sesudah maupun setelah proses pembelajaran berlangsung. 
Siswa sangat sulit melaksanakan tugas belajar jika atas inisiatif siswa sendiri. Dalam hal ini guru yang diharapkan di era merdeka belajar bukanlah guru-guru yang feodalisme, militarisme, bukanlah guru-guru yang mengandalkan paksaan apalagi paksaan disertai ancaman atau disertai symbol-simbol kekerasan. Karaketr guru yang feodalisme, militarism yang serba melakukan pemaksaan kehendak kepada anak-anak merupakan perwujudan guru yang dirasakan oleh siswa sebagai penjajah di kelas atau di sekolah. Nampaknya seiring dengan kemajuan peradaban untuk pengakuan, penghormatan dan perlindungan anak dari kekerasan telah mendapat perhatian serius dalam dunia pendidikan di Indonesia.

Apa yang menjadi sumber persoalan hingga guru di NTT pada umumnya cenderung menggunakan kekerasan dan paksaan sebagai bentuk upaya (stimulus) untuk membuat anak belajar?. Apakah memahami keliru pepatah " di ujung rotan ada emas"? karena itu rotan sebagai symbol kekerasan dipercaya guru-guru sebagai satu-satunya cara yang handal untuk membuat siswa belajar? Jika guru telah menjadikan dirinya menganut aliran " di ujung rotan ada emas", maka sungguh sangat sulit bagi seorang guru untuk berubah atas inisiatif diri sendiri tanpa ada pihak lain yang berfungsi memberi pencerahan-pencerahan bahwa sebenarnya seorang siswa dapat termotivasi untuk belajar karena guru-guru mampu dan kaya akan penyajian pembelajaran dengan variasi-variasi stimulus dan kemampuan guru menerapkan sejumlah ketrampilan mengajar yang penuh dengan kiat-kiat atau motivasi atau teknik yang kreatif, inovatif dan menyenangkan siswa.

Kelas yang kaku dan membosankan adalah contoh kelas yang dikelola oleh guru-guru yang kurang memiliki ketrampilan mengajar. Kelas yang kaku lahir dari pola pembelajaran yang kaku dan membosankan. Berbeda dengan kelas yang hidup diwarnai oleh padatnya partisipasi dan aktivitas siswa secara senang dan sukarela (merdeka belajar) yang dikelola oleh guru-guru yang professional dalam hal mempraktekkan semua ketrampilan dasar seorang pengajar.

Hasil pengamatan awal pada beberapa sekolah di Kota Kupang menunjukkan bahwa sangat mustahil terjadi iklim merdeka belajar bagi siswa, karena sebagian besar guru-guru SD yang diamati, sekalipun mereka telah lulus pelatihan atau pendidikan profesi guru tetap menganut aliran mengajar feodalisme-militarisme; tidak terjadi interaksi bercirikan kasih sayang dan humanis menyebabkan iklim belajar yang kaku dan sungguh-sungguh membosankan. Guru rata-rata berorientasi pada berapa banyak materi yang sudah diberikan kepada siswa sesuai kurikulum. Tidak ada guru yang memperhatikan kualitas proses dengan menerapakan berbagai ketrampilan dasar mengajar .

Dalam hal ini dapat diduga bahwa guru-guru membutuhkan penyegaran kembali hal-hal yang berkaitan dengan masalah paedagogik termasuk penyegaran ketrampilan dasar mengajar yang jika diterapkan secara baik akan berdampak positif mewujudkan suasana atau iklim merdeka belajar di kelas. Adapun sejumlah ketrampilan dasar mengajar guru dimaksud menurut C.Turney (1973) dalam bukunya "Sydney Micro Skills" : 1. Ketrampilan bertanya (dasar,lanjut), 2.Ketrampila memberi penguatan, 3 Ketrampilan mengadakan variasi, 4. Ketrampilan menjelaskan, 5. Ketrampilan membuka dan menutup pelajaran, 6.Ketrampilan memimpin diskusi kelompok kecil, 7. Ketrampilan mengelola kelas, 8 Ketrampilan mengajar kelompok kecil dan perorangan. 


\section{METODE}

Pengabdian kepada Masyarakat ini dilaksanakan di Aula SD GMIT Airnona 1 Kota Kupang, pada tanggal 8-10 Agustus 2020, dengan durasi pelaksanaan 3 hari. Metode yang digunakan dalam melaksanakan PkM yaitu pelatihan penyegaran dengan menggunakan multi metode terdiri dari ceramah, tanya jawab dan simulasi. Teknik pengumpulan data yang digunakan adalah Observasi dan wawancara.

\section{HASIL DAN PEMBAHASAN}

\section{Hasil}

Kegiatan Pengabdian kepada Masyarakat "Pelatihan Penyegaraan Keterampilan Dasar Mengajar Bagi Guru Sekolah Dasar di Kota Kupang” dilakukan sebagai upaya untuk meningkatkan dan menyegarkan kembali keterampilan Guru sekolah Dasar Mitra Undana dalam melaksanakan kegiatan pembelajaran. Kegiatan ini dilakukan pada hari Senin, 7 Agustus 2020 sampai dengan Senin, 9 Agustus 2020. Pertemuan ini dihadiri oleh 30 peserta (Lampiran 1) yang terdiri dari 20 guru sebagai perwakilan dari 3 sekolah Mitra Program Studi Pendidikan Guru Sekolah Dasar (PGSD), Universitas Nusa Cendana dan juga 10 orang mahasiswa PGSD. Kegiatan ini melibatkan empat Narasumber yang berasal dari Program Studi Pendidikan Guru Sekolah Dasar (PGSD), Universitas Nusa Cendana. Materi yang disampaikan antara lain pemaparan materi mengenai esensi mengajar bagi terwujudnya merdeka belajar dan 8 keterampilan dasar mengajar. Penyampaian materi dilakukan dengan 3 metode yaitu ceramah, tanya jawab dan juga praktik. Pada saat praktik dilakukan oleh mahasiswa PGSD dan melanjutkan kegiatan sebagai bentuk keberlanjutan kegiatan di sekolah masing-masing.

\section{Pembahasan}

Hasil pelaksanaan kegiatan Pengabdian kepada Masyarakat (PkM) ini, dapat dilihat berdasarkan beberapa komponen berikut.

1. Ketercapaian target jumlah peserta latihan

Target Peserta pelatihan yaitu 20 Guru dan 10 orang mahasiswa, yang merupakan perwakilan dari 3 Sekolah Mitra. Dalam pelaksanaannya, peserta yang mengikuti kegiatan PkM ini yaitu 20 Guru dan 10 mahasiswa. Dimana Hal tersebut, menunjukan bahwa target peserta pelatihan tercapai $100 \%$ atau dapat dinilai baik.

2. Ketercapaian tujuan pelatihan

Ketercapaian tujuan penulisan dapat dinilai baik. Hal ini dapat dilihat dalam antusiasme peserta pelatihan yang dilaksanakan selama kurung waktu 4 hari dan melaksanakaan tindak lanjut pada sekolah masing-masing walaupun terdapat berbagai hambatan terutama karena covid-19.

3. Ketercapaian target materi yang telah direncanakan

Ketercapaian target materi yang telah direncanakan pada kegiatan pengabdian ini dapat dinilai baik $(85 \%)$. Semua materi yang telah direncanakan dapat disampaikan kepada peserta.

4. Kemampuan peserta dalam penguasaan materi 
Kemampuan peserta dilihat dari penguasaan materi dapat dinilai baik (85\%). Hal ini mengingat pendidikan peserta pelatihan yang sudah tamat perguruan tinggi dan banyak memiliki pengalaman.

\section{SIMPULAN}

Kegiatan Pengabdian kepada Masyarakat (PkM) "Pelatihan Penyegaran Keterampilan Dasar Mengajar Bagi Guru Sekolah Dasar di Kota Kupang" berhasil membantu guru dalam mengatasi permasalahan mitra terutama dalam menyegarkan kembali mengenai tugas utama guru sebagai pengajar. Hal ini dapat dilihat dari tingkat antusiasme peserta dalam pelaksanaan pelatihan.

\section{UCAPAN TERIMA KASIH}

Kami mengucapkan limpah terimah kasih kepada :

1. Universitas Nusa Cendana Selaku tempat penulis mengabdikan diri

2. Fakultas Keguruan dan Ilmu Pendidikan Undana yang telah mendanai kegiatan PkM ini

3. SD GMIT Airnona 1 yang telah menjadi tuan rumah kegiatan PkM

4. Guru-guru SD Sekota Kupang yang telah mengikuti kegiatan PkM

5. Pihak panitia yang berkontribusi positif dalam kegiatan $\mathrm{PkM}$

DAFTAR PUSTAKA(Times New Roman 12pt, bold, spasi 1,15, left)

Abdul Majid; 2014.Strategi Pembelajaran; Rosdakarya, Bandung

Bruce Joyce,Cs ; 2016.Models Of Teaching; Pustaka Pelajar, Yogyakarta

H.Martinis Yamin; 2013.Paradigma Baru Pembelajaran; Referensi, Jakarta

Nyoman S.degeng; 2013.Ilmu Pembelajaran; Klasifikasi Variabel Untuk Pengembangan Teori dan Penelitian; Aras Media Kalam Hidup, Bandung.

Miftahul Huda; 2013. Model-Model Pengajaran dan Pembelajaran; Pustaka Pelajar, Yogyakarta 